\title{
Satisfaction Level of Policyholders in LIC'S Service With Reference To Tirupur District, Tamilnadu
}

\author{
N.Kathirvel $*$ and S.Radhamani $* *$ \\ *Assistant professor, Department of commerce, M.R.Govt Arts College, Mannargudi \\ **Ph.D (P.T), Scholar, Department of commerce, karpagam university, Coimbatore.
}

\begin{abstract}
Insurance is one of the major segments of financial market. The insurance business is unique in the sense that it is rewarded for managing the risk of other parties. In Indian insurance sector is not only playing a role within the financial system, but also has significant socio-economic functions of providing risk cover to the poor populations. Insurance provides financial protection against a loss arising out of happening of an uncertain event. The major objectives of this research are to ascertain the socio-economic profile of sample respondents and identify the satisfaction level of policyholders in LIC's services. This research has also endeavors to develop the customer satisfaction. Methodology of this study is based on the analysis of the data collected from 300 individual policy holders by using interview schedule method. The interview schedule has been prepared in such a way that the respondents are able to express their opinion freely and frankly. Primary data has been collected for this present study. The primary data was collected from three hundred sample respondents from Tirupur district, by simple random sampling method. Interview schedule was the main tool used to collect the pertinent data from the selected sample respondents. Suggested this study, the analysis it is identified that educational qualification and monthly income are found to be associated with policy holder's satisfaction. They need comfortable environment to move with officials, and new strategies to make the services offerings more effective and efficient. LIC should spread its wings in rural areas; it will enable the policy holders rather they approach in urban area. LIC has to create awareness among female policy holders, regarding the benefits of the LIC policies. To conclude this study; the policyholders of LIC are satisfied with the specified parameters concerned with taking policy. While the policyholders of LIC are more satisfied with their companies.
\end{abstract}

Keywords: policyholder's satisfaction, IRDA, LIC's service

\section{INTRODUCTION}

Life Insurance Corporation (LIC) was introduced in 1818.History of insurance in India can broadly bifurcate into two eras: a) Pre Nationalization b) Post Nationalization. LIC was nationalized in 1956.In1999, the Insurance Regulatory and Development Authority (IRDA) opened the door to private and foreign players whose share in the insurance market has been increased. The IRDA entrusted with protecting the interest of policy holders. Life Insurance is a contract for payment of a sum of money to person assured on the happening of the event insured against. The concept of customer satisfaction occupies a central position in business though and practice. Due to Growing pressures, the task of providing and maintaining customer satisfaction has become one of the most important challenges currently for companies and policy makers. Policyholder's satisfaction is equivalent to making sure that product and service performance to meet customer expectation. Today's companies are facing tough competition due to liberalized economy. Therefore, the companies can go about wining customers and out performing satisfying customer's needs. This paper makes an attempt to "analyze the satisfaction level of policyholders in LIC's service with reference to the Tirupur District".

\section{STATEMENT OF THE PROBLEM}

The insurable interest in own life is unlimited because the loss to the insured or his dependents cannot be measured in terms of money and, therefore, no limit can be played to the amount of insurance that one may take on one's own life. Thus, theoretically, a person can take a policy to any unlimited amount on his own life. The success of the life insurance business depends on the awareness of the policyholders about the products and satisfaction of the policyholders regarding the service rendered by LIC of India. As a consequence, Life Insurance Corporation has undergone increasing pressure to the policyholder offer today what they expect tomorrow. The study will also give an idea of the policy holder's requirements. Timely information is equally important as that of giving correct information. The main challenge before the insurance companies is to constantly innovate new products, ascertain changes in policyholder's behavior, government intervention, competitions, technology, distribution network, automation, technological advancement, quality in client relationship changing life styles. Societal perception and brand loyalty are the radical changes that are taken place in customer`s profile. Policy holder's satisfaction measures the important instrument to fulfill the safety 
and security needed to the people. Policy holder's satisfaction measures, across all over the world playing a major role.

\section{OBJECTIVES OF THE STUDY}

1. To ascertain the socio-economic profile of sample respondents.

2. To know the level of satisfaction of LIC`s services in selected respondents in Tirupur district.

\section{RESEARCH METHODOLOGY}

The descriptive research design was used in this study. This study uses primary data. The primary data was collected from three hundred sample respondents by using interview schedule method from Tirupur District. Samples were chosen by adopting simple random sampling method. The interview schedule has been prepared in such a way that the respondents are able to express their opinion freely and frankly .A well structured interview schedule was framed with the help of the Research Supervisor, the research experts and the LIC managers in the study area. Interview schedule was the main tool used to collect the pertinent data from the selected sample respondents. The data collected from the research are classified and tabulated. Simple statistics such as percentages and chi-square techniques are adopted in the present study in explanations to bring out the point more clearly. The sampling target groups include various types of life insurance Policyholder's in which important variables like age, income, education, occupation and no of policies are taken in to consideration.

\section{LIMITATIONS OF THE STUDY}

Time is the major constraint in collecting the data from the respondents. The market survey was conducted only in Tirupur District of Tamil Nadu. Hence, the results arrived from the study is applicable to the study area only. The samples collected have been restricted to three hundred samples only. Hence, the results of the survey cannot be generalized.

\section{ANALYSIS AND INTERPRETATION}

Table 1 showing the personal and dimorphic factors of the respondents.

\begin{tabular}{|c|c|c|}
\hline S.No & Demographics & No Of Respondents \\
\hline 1 & $\begin{aligned} & \text { Gender } \\
& \text { - } \text { Male } \\
& \text { - } \text { Female } \\
&\end{aligned}$ & $\begin{array}{l}147(49.00) \\
153(51.00)\end{array}$ \\
\hline 2 & $\begin{array}{cl}\text { Age (in years) } \\
\text { - } \quad \text { Up to } 20 \\
\text { - } \quad 21=40 \\
\text { - } \quad \text { Above } 40 \\
\end{array}$ & $\begin{aligned} 26 & (8.70) \\
207 & (69.00) \\
67 & (22.30)\end{aligned}$ \\
\hline 3 & $\begin{array}{c}\text { Education Qualification } \\
\text { - } \text { Illiterate } \\
\text { - } \text { SSLC } \\
\text { - } \text { Usc } \\
\text { - } \text { Post graduate } \\
\text { - } \text { Professional }\end{array}$ & $\begin{aligned} & 9(3.00) \\
& 35(11.70) \\
& 22(7.30) \\
& 76(25.30) \\
& 126(42.00) \\
& 32(10.70) \\
&\end{aligned}$ \\
\hline 4 & $\begin{array}{cl}\text { Marital } & \text { status } \\
\text { - } & \text { Married } \\
\text { - } & \text { Unmarried }\end{array}$ & $\begin{array}{ll}167 & (55.70) \\
133 & (44.30)\end{array}$ \\
\hline 5 & $\begin{array}{cl}\text { Area of Residence } \\
\text { - } \\
\text { - } \text { Srban } \\
\text { - } \text { Rural } \\
\end{array}$ & $\begin{aligned} & 111(37.00) \\
& 85(28.30) \\
& 104(34.70) \\
&\end{aligned}$ \\
\hline 6 & $\begin{array}{cl}\text { Occupation } \\
\text { - } & \text { Daily wage Earners } \\
\text { - } & \text { Agriculturist } \\
\text { - } & \text { Employee } \\
\text { - } & \text { Professiness } \\
\text { - } & \text { Student } \\
\text { - } & \text { Housewife }\end{array}$ & $\begin{aligned} 6 & (2.00) \\
31 . & (10.30) \\
97 & (32.30) \\
36 & (12.00) \\
24 & (8.00) \\
74 & (24.70) \\
32 & (10.70)\end{aligned}$ \\
\hline 7 & Family income & \\
\hline
\end{tabular}




\begin{tabular}{|c|c|c|}
\hline & $\begin{array}{ll}\text { - } & \text { Up to Rs } 15000 \\
\text { - } & \text { Rs } 15000 \text { to Rs } 30000 \\
\text { - } & \text { Above Rs } 30000 \\
\end{array}$ & $\begin{array}{rr}34 & (11.30) \\
150 & (50.00) \\
116 & (38.70) \\
\end{array}$ \\
\hline 8 & $\begin{array}{c}\text { Status in the Family } \\
\text { - Head } \\
\text { - Member }\end{array}$ & $\begin{aligned} 83 & (27.70) \\
217 & (72.30)\end{aligned}$ \\
\hline 9 & $\begin{aligned} \text { Type of Family } \\
\text { - Joint } \\
\text { - Nuclear }\end{aligned}$ & $\begin{array}{l}172 \\
128\end{array}$ \\
\hline 10 & $\begin{array}{c}\text { No of Family Members } \\
\text { Up to three } \\
\text { Four and above }\end{array}$ & $\begin{array}{ll}149 & (49.70) \\
151 & (50.30)\end{array}$ \\
\hline
\end{tabular}

$>51 \%$ of the policyholders are Females.

$>$ Respondents whose age ranges between 21 years and 40 years are majority avail insurance policies.

> $42 \%$ of the respondents are with post graduates as their education qualification.

$>$ Most of the respondents are married.

37\% of the respondents reside in an urban area.

$>$ Large sections of the policy holders are employed.

$>$ Half of the policyholder's income ranges between Rs 15000 and Rs30000.

$>$ Majority of the respondent belongs to member`s category.

$>57.30 \%$ of the respondents belongs to joint family.

$>$ Most of the policy holders have more than three family members.

\section{DETERMINANTS OF POLICY HOLDER'S SATISFACTION}

Table2: Showing the Age with policy holder satisfaction.

\begin{tabular}{|c|c|c|c|c|c|c|c|c|}
\hline \multirow{3}{*}{ Age } & \multicolumn{9}{|c|}{ Level of Satisfaction } & \multicolumn{2}{c|}{ Total } \\
\cline { 2 - 10 } & \multicolumn{2}{|c|}{ Low } & \multicolumn{2}{c|}{ Moderate } & \multicolumn{2}{c|}{ High } & \multicolumn{2}{c|}{} \\
\cline { 2 - 10 } & No. & $\mathbf{\%}$ & No. & \% & No & \% & No. & $\%$ \\
\hline Up to20 & 4 & 15.4 & 16 & 61.5 & 6 & 23.1 & 26 & 100 \\
\hline $21-40$ & 27 & 13.0 & 142 & 68.6 & 38 & 18.4 & 207 & 100 \\
\hline Above 40 & 10 & 14.9 & 50 & 74.6 & 7 & 10.4 & 67 & 100 \\
\hline Total & $\mathbf{4 1}$ & $\mathbf{1 3 . 7}$ & $\mathbf{2 0 8}$ & $\mathbf{6 9 . 3}$ & $\mathbf{5 1}$ & $\mathbf{1 7}$ & $\mathbf{3 0 0}$ & $\mathbf{1 0 0}$ \\
\hline
\end{tabular}

Null Hypothesis: There is no significant relationship between Age and level of satisfaction.

Result: Chi- square test reveals that the calculated value of chi- square 3.189 is less than the table value at $5 \%$ level $(x 2=3.189<9.488)$ so the null hypothesis is accepted. There is no significant relationship between age and level of satisfaction.

Table 3 showing the Educational Qualification with policy holder satisfaction

\begin{tabular}{|l|c|c|c|c|c|c|c|c|}
\hline \multirow{2}{*}{$\begin{array}{c}\text { Educational } \\
\text { Qualification }\end{array}$} & \multicolumn{6}{|c|}{ Level of Satisfaction } & \multicolumn{2}{c|}{ Total } \\
\cline { 2 - 10 } & \multicolumn{2}{|c|}{ Low } & \multicolumn{2}{c|}{ Moderate } & \multicolumn{2}{c|}{ High } & \multicolumn{2}{c|}{} \\
\cline { 2 - 10 } & No. & $\mathbf{\%}$ & No. & \% & No. & \% & No. & \% \\
\hline Illiterate & 1 & 11.1 & 7 & 77.8 & 1 & 11.1 & 9 & 100 \\
\hline SSLC & 5 & 14.3 & 23 & 65.7 & 7 & 20.0 & 35 & 100 \\
\hline HSC & 1 & 4.5 & 21 & 91.5 & 0 & 0 & 22 & 100 \\
\hline Under Graduate(UG) & 12 & 15.8 & 50 & 65.8 & 14 & 18.4 & 76 & 100 \\
\hline Post Graduate(PG) & 18 & 14.3 & 81 & 64.3 & 27 & 21.4 & 126 & 100 \\
\hline professional & 4 & 12.5 & 26 & 81.3 & 2 & 6.3 & 32 & 100 \\
\hline Total & $\mathbf{4 1}$ & $\mathbf{1 3 . 7}$ & $\mathbf{2 0 8}$ & $\mathbf{6 9 . 3}$ & $\mathbf{5 1}$ & $\mathbf{1 7}$ & $\mathbf{3 0 0}$ & $\mathbf{1 0 0}$ \\
\hline
\end{tabular}

Null Hypothesis: There is no significant relationship between Educational Qualification and Level of Satisfaction. 
Result: Chi- square test reveals that the calculated value of chi- square 21.118 is greater than the table value at $5 \%$ level $\left(\mathrm{x}^{2}=21.118>18.307\right)$ so the null hypothesis is rejected. There is significant relationship between Educational Qualification and Level of Satisfaction.

Table 4 showing the Occupation with policy holder satisfaction

\begin{tabular}{|c|c|c|c|c|c|c|c|c|}
\hline \multirow{3}{*}{ Occupation } & \multicolumn{6}{|c|}{ Level of Satisfaction } & \multirow{2}{*}{\multicolumn{2}{|c|}{ Total }} \\
\hline & \multicolumn{2}{|c|}{ Low } & \multicolumn{2}{|c|}{ Moderate } & \multicolumn{2}{|c|}{ High } & & \\
\hline & No. & $\%$ & No. & $\%$ & No. & $\%$ & No. & $\%$ \\
\hline $\begin{array}{l}\text { Daily Wage } \\
\text { Earners }\end{array}$ & 1 & 16.7 & 5 & 83.3 & 0 & 0 & 6 & 100 \\
\hline Agriculturist & 6 & 19.4 & 22 & 71.0 & 3 & 9.7 & 31 & 100 \\
\hline Employee & 14 & 14.4 & 68 & 70.1 & 15 & 15.5 & 97 & 100 \\
\hline Business & 6 & 16.7 & 25 & 69.4 & 5 & 13.9 & 36 & 100 \\
\hline Professional & 1 & 4.2 & 20 & 83.3 & 3 & 12.5 & 24 & 100 \\
\hline Student & 8 & 10.8 & 48 & 64.9 & 18 & 24.3 & 74 & 100 \\
\hline Housewife & 5 & 15.6 & 20 & 62.5 & 7 & 21.9 & 32 & 100 \\
\hline Total & 41 & 13.7 & 208 & 69.3 & 51 & 17 & 300 & 100 \\
\hline
\end{tabular}

Null Hypothesis: There is no significant relationship between Occupation and level of satisfaction.

Result: Chi- square test reveals that the calculated value of chi- square9.871 is less than the table value at $5 \%$ level $(\mathrm{x} 2=9.871<21.026)$ so the null hypothesis is accepted. There is no significant relationship between Occupation and Level of Satisfaction.

Table 5 showing the Monthly income with policy holder satisfaction

\begin{tabular}{|l|c|c|c|c|c|c|c|c|}
\hline \multirow{3}{*}{$\begin{array}{c}\text { Monthly } \\
\text { Income }\end{array}$} & \multicolumn{6}{|c|}{ Level of Satisfaction } & \multicolumn{3}{|c|}{ Total } \\
\cline { 2 - 10 } & \multicolumn{2}{|c|}{ Low } & \multicolumn{2}{c|}{ Moderate } & \multicolumn{2}{c|}{ High } & \multicolumn{2}{|c|}{} \\
\cline { 2 - 10 } & No. & $\mathbf{\%}$ & No. & \% & No. & \% & No. & $\%$ \\
\hline $\begin{array}{l}\text { Up to } \\
\text { Rs.7500 }\end{array}$ & 9 & 8.3 & 74 & 68.5 & 25 & 23.1 & 108 & 100 \\
\hline $\begin{array}{l}\text { Rs.7501- } \\
\text { Rs.15000 }\end{array}$ & 18 & 18.4 & 66 & 67.3 & 14 & 14.3 & 98 & 100 \\
\hline $\begin{array}{l}\text { Above } \\
\text { Rs.15000 }\end{array}$ & 14 & 14.9 & 68 & 72.3 & 12 & 12.8 & 94 & 100 \\
\hline Total & $\mathbf{4 1}$ & $\mathbf{1 3 . 7}$ & $\mathbf{2 0 8}$ & $\mathbf{6 9 . 3}$ & $\mathbf{5 1}$ & $\mathbf{1 7}$ & $\mathbf{3 0 0}$ & $\mathbf{1 0 0}$ \\
\hline
\end{tabular}

Null Hypothesis: There is no significant relationship between Monthly Income and level of satisfaction.

Result: Chi- square test reveals that the calculated value of chi- square 12.942 is greater than the table value at $5 \%$ level $\left(x^{2}=12.942>9.488\right)$ so the null hypothesis is rejected. There is significant relationship between Monthly Income and Level of Satisfaction

Table 6 showing the Number of policies with policy holder satisfaction

\begin{tabular}{|c|c|c|c|c|c|c|c|c|}
\hline \multirow{3}{*}{$\begin{array}{c}\text { Number } \\
\text { of } \\
\text { Policies }\end{array}$} & \multicolumn{6}{|c|}{ Level of Satisfaction } & \multirow{2}{*}{\multicolumn{2}{|c|}{ Total }} \\
\hline & \multicolumn{2}{|c|}{ Low } & \multicolumn{2}{|c|}{ Moderate } & \multicolumn{2}{|c|}{ High } & & \\
\hline & No. & $\%$ & No. & $\%$ & No. & $\%$ & No. & $\%$ \\
\hline One & 26 & 18.4 & 94 & 66.7 & 21 & 14.9 & 141 & 100 \\
\hline Two & 12 & 10.5 & 80 & 70.2 & 22 & 19.3 & 114 & 100 \\
\hline Three & 3 & 6.7 & 34 & 75.6 & 8 & 17.8 & 45 & 100 \\
\hline Total & 41 & 13.7 & 208 & 69.3 & 51 & 17 & 300 & 100 \\
\hline
\end{tabular}

Null Hypothesis: There is no significant relationship between Number of policies and level of satisfaction. 
Result: Chi- square test reveals that the calculated value of chi- square9.871 is less than the table value at $5 \%$ level $(\mathrm{x} 2=5.932<9.488)$ so the null hypothesis is accepted. There is no significant relationship between number of policies and Level of Satisfaction.

\section{FINDINGS OF THE STUDY}

1. Youngsters have high level of satisfaction. The policyholders who are below the age 20 years high level of satisfaction at 5\% level. There is no significant relationship between age and level of satisfaction.

2. Post graduate policy holders have high level of satisfaction. The policies holders complete under graduate qualification have low level of satisfaction. From this it is identify that Educational Qualification are found to be associated with policy holder's satisfaction.

3. The student populations have high level of satisfaction. The agriculturists have low level of satisfaction. There is no significant relationship between Occupation and Level of Satisfaction.

4. Monthly income aboveRs 15000 policy holders have high level of satisfaction. The policy holder's monthly income ranges between Rs 7501 and Rs 15000 have low level of satisfaction. From this it is identify that monthly income are found to be associated with policy holder's satisfaction.

5. Those are having more than two policies have high level of satisfaction. Those are having only one policy they have low level of satisfaction. There is no significant relationship between Number of policies and level of satisfaction.

\section{SUGGESTIONS AND RECOMMENDATIONS}

1. First of all LIC have to create a new structure of policy for youngsters and juniors even after being offered Varity of policies already in the track that will induce the youngsters and juniors to take more policies.

2. LIC should spread its wings in rural areas; it will enable the policy holders rather they approach in urban area.

3. Lower and middle class people unable to make premium payment in time. So, the number of installments should be raised.

4. LIC has to create awareness among female policy holders, regarding the benefits of the LIC policies.

5. Those who are below 20 years should be taught and well equipped about LIC then only they will have interest to joint in LIC.

6. The females are not interested because of their ignorance, in fact LIC have to educate females about the LIC policies, LIC can offer more benefits, and flexible while taking policies. LIC should create awareness among females and lower class people.

7. The under graduate are not having apropos knowledge about LIC, en bloc we can educate Illiterates, and Agriculturists through frequent advertisement.

8. The income ranges between Rs. 7501 andRs. 15000 are not satisfied because of their incapable of payments. Since their financial positions are very low LIC have to reduce the premium amount accordingly to their financial status. They can pay the premium amount periodically, if at all it is affordable.

9. Considering the policyholder taste LIC can change the office environment to meet their requirements easily, they can approach and clarify their doubts. The main thing is the policyholders should have comfortable environment to move with officials.

10. There is a need of hour for the insurance company to reorient themselves in terms of the customer service parameters to instill the concept of customer satisfaction in the mind of the customer and further in terms of growth.

11. To increase the level of insurance penetration LIC may focus on bringing products that suit to the female customer.

12. The company, if possible should invest in advertising, conduct road shows, and spend money on hoardings, so that it can create awareness about its unknown products.

13. Some special focus should be laid on individual risk coverage while designing the products to agriculturalists.

14. Procedure formalities may be simplified.

As Life Insurance Corporation is progressing towards growth and development, these suggestions may increase efficiency of the LIC.

\section{CONCLUSION}

The majority of the policy holders are satisfied with LIC`s service. This shows that female and agricultural policy holders have not understood clearly about the purpose of insurance, so it is suggested that the life insurance company should conduct insurance awareness campaign with the help of advertisements and social groups. The awareness on insurance has to be increase in their early age. In the emerging boom the insurance company, every insurance company should be customer centered, should be well versed in the 
handling of problem and grievances of the policy holders. Each and every product and services launched by the insurance company should be in favour of increasing need of policy holders. IRDA should be more and more responsible to the insurance sector by determining some standard. It should be mandatory to every insurer to make more and more responsible and responsive to the policy holders.

\section{References}

[1] Dr. V.RamaDevi and A.Ramesh "Life insurance industry in India" life insurance today Vol: IV NO: 1 APR 08 pp10-14

[2] Dr. K.Srinivasa Rao and Dr.P.Malyadri" Customer service in insurance industry: Challenges ahead" the insurance times Vol:XXVIII No:7 July 2008 pp-29-32

[3] SSN Raju indukoori "Expectations Management A tool for Enhancing customer satisfaction"Vol: III issue II insurance chronicle Feb 08 pp 25-31.

[4] VOICE Survey (2006) on "Customer's satisfaction in Insurance sector," Consumer voice Vol 7(3) May-June.

[5] Mony S.V (2005) "New Initiatives in the Insurance sector: opportunities and challenges" Vikal pa Vol: $30(3)$ pp 102 -105.

[6] K.Paramasivam," Diversification of life insurance products-An endless process" life insurance today Vol:IV no:3June2008 pp 5-8 